\title{
Industrialized Building System (IBS) Provision in Local and International Standard Form of Contracts
}

\author{
"Mohd Ashraf Mohd Fateh' and Mohammad Fadhil Mohammad²
}

\begin{abstract}
Published online: 15 January 2018
To cite this article: Mohd Ashraf Mohd Fateh and Mohammad Fadhil Mohammad. (2017). Industrialized building system (IBS) provision in local and international standard form of contracts. Journal of Construction in Developing Countries, 22(2): 67-80. https://doi.org/10.21315/jcdc2017.22.2.5
\end{abstract}

To link to this article: https://doi.org/10.21315/jcdc2017.22.2.5

\begin{abstract}
Industrialized Building System (IBS) has been introduced for over 40 years in Malaysia, with well-documented benefits and strong support from the government. Unfortunately, the pace of IBS adaptation is still slow and below the government's target. Construction players are still facing various issues and challenges when adopting IBS, particularly on contractual and procurement aspects, thus, it contributes to the low adoption of IBS in Malaysia. As of to date, there is still the lack of provisions in Malaysian standard form of contract to suit the IBS construction approach. Therefore, this research will attempt to investigate and compare several local and international standard form of contracts to identify and highlight what international standard form of contracts have provisions to suit IBS construction approach. Literature review and documents analysis were used in the data collection exercise. The study revealed that there are six provisions that the local standard form of contract can enhance to suit the IBS construction approach. The findings will be useful to enhance the local standard form of contract to suit IBS construction approach, hence, able to accelerate the adoption of IBS construction in Malaysia.
\end{abstract}

Keywords: IBS, Standard form of contract, Contract, Procurement, Malaysia

\section{INTRODUCTION}

Malaysia has experienced significant economic growth over the past 5 years at a steady rate of $6 \%$ per annum as reported by Construction Industry Development Board (CIDB) (2015a). The construction industry also offers large scale positive spillover effects onto both the manufacturing and services sectors. Based on the report by the CIDB (2015b), the construction industry accounts for $15 \%$ of the total output of Malaysia's manufacturing sector. The construction industry has been a real catalyst for the economic development enjoyed in recent years, as infrastructure development has been at the core of both the Economic Transformation Program (ETP) and the Tenth Malaysia Plan. Back in September 2015, CIDB presented the Construction Industry Transformation Programme 2016-2020 (CITP). CITP'S vision is to transform the construction industry to become highly productive, sustainable, and globally competitive while raising the professional bar in the industry. One of the key initiatives in raising the productivity of the construction workforce is to drive higher technology adoption used in advanced construction methods (Industrialized Building System or (BS). Malaysian government has always been committed to

\footnotetext{
'Faculty of Engineering and Technology Infrastructure, Infrastructure University Kuala Lumpur (IUKL), 40300 Kajang, Selangor, MALAYSIA

${ }^{2}$ Faculty of Architecture Planning and Surveying, Universiti Teknologi Mara (UiTM), 40450 Shah Alam, Selangor, MALAYSIA

"Corresponding email: mohd.ashraf.fateh@gmail.com
} 
address IBS as national agenda based on the findings by Kamaruddin et al. (2013). Numerous initiatives have been done throughout the years namely Construction Industry Master Plan (CIMP) in 2006, IBS roadmap in 2010, and CITP in 2015. Although numerous efforts have been done to push IBS adoption, the adoption rate is still low as reported by CIDB (2010). Many types of research have been conducted on IBS but the focus is more only on product, construction process, and technical aspects. According to Abd Jalil et al. (2016) there is an evident lack of research on procurement for adopting IBS construction approach. Therefore, this paper will focus on the provision in the local and international standard form of contracts for IBS construction approach. This research will give an insight of information and guidance to all the related stakeholders such as CIDB, Public Works Department (PWD), expert panels, academicians, and related IBS players. The challenges in boosting the adoption of IBS projects would be looking at the enhancement of the standard form of contract for IBS construction approach. It will give a valueadded impact on the adaptation of IBS construction approach. This was supported by CIDB (2006), which stated that a suitable standard form of contract for IBS will invariably expedite the project success.

This paper is structured into three parts. Firstly, the review covers a broad range of literature providing an overview of the construction industry, IBS scenario in Malaysia, and the standard form of contract widely used in the industry. The second part discusses the methodology used for this research. The last part discusses findings and conclusions derived from evidence from the literature review and the document analysis.

\section{The Construction Industry}

The construction industry is one of the complex industries and a challenging sector. It needs to be conducted properly and wisely to avoid the emergence of problems that can affect the overall project. The nature of the complex construction industry also requires an efficient work process and a strong relationship between the parties involved in the construction industry as stated by Zakaria, Ismail and Md Yusof (2013). According to Harmon (2003), it can derail a project and lead to complicate dispute, increased costs, delay, and breakdown in parties communication and relationship. Furthermore, Hellard (1997) stated that the causes of dispute are all because of the complexity and nature of the project, contract, and the contractual relationship between each other that consequently lead to misunderstanding and failure of performing. It is supported by Broome and Hayes (1997) who reported that contractual conflicts or disputes seem to be inevitable in the construction industry, especially on issues concerning interpretation and understanding of construction contracts. Heap, Balamuralithara and Chong (2011) stated that construction industry stakeholders always use a standard form of contract to regulate their contractual obligations and expectations during the contract administration process. It is during this process that a vast amount of contract provisions are referred to.

\section{IBS in Malaysia}

According to CIDB (2014), IBS is defined as a construction technique in which components are manufactured in a controlled environment (on or offsite), transported, positioned, and assembled into a structure with minimal additional 
site work. Various previous researches done (Construction Research Institute of Malaysia [CREAM], 2011; Sarja, 1998; Gibb, 2001; The UK Government Department of Trade and Industry [DTI], 2004; Nawi et al., 2011; Mohamad Kamar et al., 2009; CIDB, 2015a; Mohammad, 2013; Abd Shukor, Mohammad and Mahbub, 2011 ; Musa et al., 2015; Muhamad Halil et al., 2015; Kamaruddin, Mohammad and Mahbub, 2013) have proved that using IBS offer huge benefits in terms of cost and time certainty, attaining better construction quality and productivity. Although IBS has been introduced for over 40 years in Malaysia, with well-documented benefits and strong support from the government, the pace of implementation and usage of IBS is still slow and below the government's target as reported by CIDB (2015a) and Nawi et al. (2011). This was agreed by Abd Jalil et al. (2016) who reported that the adoption of IBS has been recognised but the progress of adaptation has been very low and slow. Previous research was done by Mohamad Kamar, Alshawi and Abd Hamid (2009) concluded that since there is no specific procurement method for IBS projects, many problems on the project delivery system have arisen thus becoming barriers for IBS adoption. Industry players do not have any reference or guidelines for IBS construction approach. This was agreed by Abd Jalil et al. (2016) who stated that the reference and guideline they have are only related to product based information. This scenario will lead to confusion and dispute during the construction period. According to Chung and Kadir (2007), stressed that IBS players need to refine and adapt the existing contract and procurement options chosen, to suit the new IBS construction approach adopted in the projects. While Abd Hamid et al. (2011) highlighted that performance of the project may be badly affected if the client chooses unsuitable procurement methods.

According to Mohd Fateh, Mohammad and Abd Shukor (2016) and Mohamad Kamar, Alshawi and Abd Hamid (2009) stated that the construction players are still facing some issues and challenges in contractual aspects when adopting IBS, thus it contributes to the low adoption of IBS in Malaysia. Based on the preliminary study being done by Mohd Fateh, Mohammad and Abd Shukor (2016) stated that all respondents agreed that it is a necessity to enhance the existing Malaysia's standard form of contract to suit IBS construction approach. Therefore, this research is to enhance the existing provision in Malaysia's standard form of contract to suit IBS construction approach, hence propel the acceleration adoption of IBS construction approach parallel with the CITP's vision.

\section{Standard Form of Contract}

The standard form of contract can be defined as a printed form and published by an authoritative body of the industry, which is recognised by both parties in the contract as reported by Singh (2011 b), Zolkafli@Zulkifli et al., (2011), and Mahdi (2001). The forms set out the terms or condition on which the contract between the parties is to be carried out. According to Singh (2011b) even as a small country, Malaysia boasts of quite a number of standard form of contract in the construction industry to name a few Public Work Department (PWD) series, Pertubuhan Arkitek Malaysia (PAM) series, and Institute Engineer Malaysia (IEM) series. Each series offers different project owner/employer, type of project as well as the nature of project activities and financing involved reported by Zakaria, Ismail and Md Yusof (2013). As highlighted by Singh (201 la) and Zakaria, Ismail and Md Yusof (2013), the purposes of the standard of form contract are as follows: 
1. Provide the basic legal framework evidencing the legal relationship between the parties.

2. Furnish a mechanism for regulation the conduct of the commercial relationship between parties.

3. Put in place the administrative procedures necessary to effect the legal and commercial relationship between parties.

4. Establish the ambit of powers and duties of the contract administrators under the contract between the parties.

5. To facilitate the contractual arrangements between all players in a project.

In summary, the standard form of contract is multifold governing not only legalities but also administrative issues to ensure that both parties are able to discharge and can actually discharge their side of the bargain through full performance as stated by Singh (2011 b) and Zakaria, Ismail and Md Yusof (2013). Wilkinson and Scofield (2010) identified that the choice of the standard form of contract is as having a significant impact on the achievement of time, cost and quality targets for a project. Zakaria, Ismail and Md Yusof (2013) also add up that the selection of forms of contract depend on pricing and the contract strategy that best meet the project objectives. Different types of contract offer different ways of handling pricing, risk transfer, responsibility for performance, cost certainty, and complexity. Among the primary reasons attributed to these problems are the lack of clarity and use of legalese in the contract clauses as reported by Heap, Balamuralithara and Chong (2011). Therefore, understanding and using the suitable standard form of contract is necessary to ensure the process of managing the project goes smoothly.

According to Zakaria, Ismail and Md Yusof (2013), the selection forms of contract are a crucial factor in the performance of a construction project. It shows that the use of contract documents is dependent on the project owner/employer, type of project as well as the nature of a project and financing involved. According to Ramus and Birchall (1996), choosing an inappropriate standard form of contract will increase disputes as the objectives of the project are not fully achieved in terms of time, cost, and quality. Usually, the selection is done based on the project owner or respective agents familiarity on the forms as rather on a predetermined criteria as reported by Ting and Chin (2013). Based on the questionnaire survey done by Ting and Chin (2013), the most important selection criteria is the nature of work, which includes size, the level of complexity, type, and source of funding of the project. According to Jaafar and Radzi (2012), they concluded that the procurement system in Malaysia has not evolved greatly since the colonial British era. Many clients in the local industry prefer to choose procurement systems considered familiar, even though the criteria and purposes or every project are different. Previous research by Mohd Fateh, Mohammad and Abd Shukor (2016) stated that every project is unique and dynamic in terms of processes, resource allocation, risk exposure, and responsibilities between all parties. Therefore, there is a necessity to enhance the existing Malaysia standard form of contract for IBS construction approach in Malaysia. This was agreed by Jaafar and Radzi (2013) who suggested that when there are changes in the method of construction, there is also a need to adopt a new procurement system. Using unsuitable procurement methods in IBS will not only affect the progress of the project but also will affect the construction team in terms of understanding and interpretation of the regulation. According to Gandu, Ali and Chindo (2009) and Preuss (2009), the system of procurements is considered 
as the key to project success. Blismas and Wakefield (2009) also agreed to this, that in producing a successful IBS project, the procurement approach must be suitable. Findings by Abd Jalil et al. (2016) highlighted that a specific procurement system is required as IBS construction approach involves special producers and processes that are different to traditional construction. Previous researchers had concluded that the current traditional standard form of contract was not suitable for IBS construction approach, especially in terms of payment and project coordination as reported by Abd Jalil et al. (2016). This was agreed by Mohamad Kamar, Alshawi and Abd Hamid (2009), who reported that the existing standard form of contract does not favour the industry players that want to adopt IBS construction approach. IBS Centre (2007) also highlighted that several of the barriers factors that hinder the adoption of IBS construction approach are the lack procurement method and provision in the standard form of contract.

To date, there is still a lack of provisions in the Malaysia standard form of contract to suit the IBS construction approach as reported by Mohd Fateh, Mohammad and Abd Shukor (2016). This was agreed by Abd Jalil et al. (2016) who stated that despite the various government efforts in pushing IBS as national agenda (IBS roadmap, CIMP and CITP), there are no detailed IBS building guidelines or standard regulations for procurement systems or contract documents in term of tendering, design, construction, and operation that have been produced. Research by Abd Jalil et al. (2016) added up that current standard form of contract has not addressed this very pertinent issue. Therefore, this research will attempt to investigate and compare a number of standard forms of contract locally and internationally to identify and highlight what other standard forms of contract have provisions to suit IBS construction approach.

\section{METHODOLOGY}

Literature review and documents analysis were used in the data collection exercise. For the first phase, literature review derived from relevant books, journals articles, thesis and dissertations, conference proceedings, and reports were examined. For the second phase seven standard form of contract were analysed for documents analysis as follows:

1. PWD 203A (Malaysia)

2. PWD DB (Malaysia)

3. PAM 2006 (Malaysia)

4. Public Sector Standard Form of Contract for Construction Works 2014 (Singapore)

5. FIDIC 2010 (Switzerland)

6. Australian Standard 4300 (Australia)

7. JCT 2011 (UK).

The document analysis was done to investigate and make the comparison on each standard form of contract in terms of provision for IBS. By doing so, the findings can understand the full spectrum on how standard forms of contract from other countries incorporate provision for IBS construction approach. However, since this research is still ongoing as this paper is being written, the data presented in this paper is only based on the summary findings from the literature review and document analysis. 


\section{RESULTS AND DISCUSSION}

\section{PWD Series Standard Form of Contract (Malaysia)}

PWD series was the initial sets of the standard form of contract drafted by the various government agencies working in public sector as reported by Singh (2011 b). It is being modelled on the Royal Institute of British Architects (RIBA) back in 1931. According to Ashworth (2006), this type of contract separate the construction and design activities. The design team is contracted by the client, and they shall provide the contractor with a complete design for construction. Over the years, the standard form of contract was modified to suit local conditions and to keep up with the industry developments.

\section{PAM Series Standard Form of Contract (Malaysia)}

Parallel with the government sector, the private sector also developed their own standard form of contract. The Pertubuhan Akitek Malaysia (PAM) takes the initiatives by delivering the PAM series mainly for the building works as stated by Singh (2011 b). The PAM series are used extensively in the Malaysian building industry. It is estimated that $90 \%$ of the building works in the private sector used the PAM series as reported by Rajoo, Davidson and Singh (2010), Malaysian Construction and Contract Law (2012), and Zakaria, Ismail and Md Yusof (2013). Research by Zakaria, Ismail and Md Yusof (2013) also add up that the risks are known to the local industry players and widely used by the building contractor. The PAM series also has been through review and amendments over the years to suit the construction industry needs.

\section{AS Series Standard Form of Contract (Australia)}

According to Sharkey et al. (2014) the range of standard forms available in Australia has its origins in the forms promulgated by professional bodies in the late 19th and early 20th centuries in the United Kingdom. The Australian Standards (AS) major works standard forms are used across all sectors (other than for residential building with a private individual as principal) and across all contracting values as reported by Sharkey et al. (2014). Typically, the standard forms have evolved by a process whereby a consensus is forged among various industry interest groups and reflected in a standard form; that form becomes increasingly the subject of amendments and revision.

\section{PSSCOC Standard Form of Contract (Singapore)}

In Singapore, the Public Sector Standard Conditions of Contract (PSSCOC) was developed to enable a common contract form to be used in all public sector construction projects. Standardisation will increase familiarity among users, reduce tendering efforts, and promote greater efficiency in contract administration. The PSSCOC is widely used for public sector construction projects. First published in 1995, second and third editions were launched in July 1999 and January 2004, respectively. The fourth edition was launched in March 2005 as reported by Building and Construction Authority (2015). 


\section{FIDIC Standard Form of Contract (Switzerland)}

The International Federation of Consulting Engineers (FIDIC), with its headquarters located in Geneva, Switzerland, in association with the European International Federation of Construction (FEIC) produces a whole series of standard form of contract for use worldwide with amendments if necessary to suit legal system of the country of a particular application as stated by Singh (2011 b). According to Ahmad Smore (2007), FIDIC is recommended for building or engineering works designed by the employer, or by his representative, the engineer. The contractor will construct the work based on the design by the employer, which includes civil, mechanical, and electrical works. FIDIC standard form of contract has been applied worldwide, especially in the projects invested or financed by the World Bank, Asia Development Bank, and African Development Bank as stated by Zakaria, Ismail and Md Yusof (2013).

\section{JCT Standard Form of Contract (United Kingdom)}

The Joint Contracts Tribunal (JCT) formed in 1931 is an affiliation of interest groups within the British construction industry, which operates as a forum for discussing and determining the content of the clauses of the standard form of building contracts as stated by Singh (2011 b) and The Joint Contracts Tribunal Limited (2016). The usage of JCT goes back further to the 19th century reported by The Joint Contracts Tribunal Limited (2016). It regularly amends the standard form of contracts with supporting documentation and practice notes. Even though JCT standard forms of contract have been rarely used in Malaysia but it is widely used in the United Kingdom. JCT is the leading provider of contract documentation, which not only covers standard forms of main and sub-contracts for each of the key procurement methods, but also guidance documents, homeowner contracts, partnering documentation, collateral warranties, and agreements as stated by The Joint Contracts Tribunal Limited (2016).

\section{Documents Analysis}

Seven standard form of contract were chosen for the documents analysis as stated in the methodology section. The justification is because the standard form of contract is current and widely used in the respective countries. All clauses from each standard form of contract were examined and interpreted to get a better understanding. From the analysis, there are six provisions that the local standard form of contract can enhance, therefore enabling it to tailor the IBS construction approach. Table 1 illustrates the summary of findings from the document analysis.

\section{i. Definition of unfixed material and goods}

For all Malaysia's standard form of contract, the unfixed material and goods need to be onsite. Meanwhile, all international standard form of contract acknowledges that the unfixed material and goods can be onsite or offsite. For PSS 2014, it stated that it can be at the place of manufacture, fabrication or preparation or onsite or at such other place specified in the contract. In AS 4300, it stated for the unfixed material and goods can be offsite provided that the 
contractor furnishes information such as the mode/place of manufacturer, the source of supply, the performance capacities, and other related information required by the client. While in JCT 2011, it stated as, for material and/or prefabricated items (offsite), it needs to be listed by the client. This is a good provision because, in IBS construction approach, most of the activities will be done offsite or prefabrication. It can be either at a factory or fabrication yard.

Table 1. Summary of Findings from the Document Analysis

\begin{tabular}{|c|c|c|c|c|c|c|c|c|}
\hline No. & Provisions & $\begin{array}{c}\text { PWD 203A } \\
2010\end{array}$ & $\begin{array}{c}\text { PWD DB } \\
2010\end{array}$ & $\begin{array}{l}\text { PAM } \\
2006\end{array}$ & $\begin{array}{l}\text { PSS } \\
2014\end{array}$ & $\begin{array}{l}\text { FIDIC } \\
2010\end{array}$ & $\begin{array}{c}\text { AS } \\
4300\end{array}$ & $\begin{array}{l}\text { JCT } \\
2011\end{array}$ \\
\hline 1 & $\begin{array}{l}\text { Definition of unfixed material } \\
\text { and goods } \\
\text { - Need to be onsite } \\
\text { - Can be offsite }\end{array}$ & $\sqrt{ }$ & $\sqrt{ }$ & $\sqrt{ }$ & $\begin{array}{l}\sqrt{ } \\
\sqrt{ }\end{array}$ & $\sqrt{ }$ & $\begin{array}{l}\sqrt{ } \\
\sqrt{ }\end{array}$ & $\begin{array}{l}\sqrt{ } \\
\sqrt{ }\end{array}$ \\
\hline 2 & $\begin{array}{l}\text { Evaluation of interim payment } \\
\text { - Progress work done } \\
\text { - Material onsite } \\
\text { - Material offsite }\end{array}$ & $\begin{array}{l}\sqrt{ } \\
\sqrt{ }\end{array}$ & $\begin{array}{l}\sqrt{ } \\
\sqrt{ }\end{array}$ & $\begin{array}{l}\sqrt{ } \\
\sqrt{ }\end{array}$ & $\begin{array}{l}\sqrt{ } \\
\sqrt{ } \\
\sqrt{ }\end{array}$ & $\begin{array}{l}\sqrt{ } \\
\sqrt{ }\end{array}$ & $\begin{array}{l}\sqrt{ } \\
\sqrt{ } \\
\sqrt{ }\end{array}$ & $\begin{array}{l}\sqrt{ } \\
\sqrt{ } \\
\sqrt{ }\end{array}$ \\
\hline 3 & $\begin{array}{l}\text { Inspection, testing of material, } \\
\text { goods and equipment } \\
\text { - Already incorporated onsite } \\
\text { - Not yet incorporated onsite }\end{array}$ & $\begin{array}{l}\sqrt{ } \\
\sqrt{ }\end{array}$ & $\sqrt{ }$ & $\sqrt{ }$ & $\begin{array}{l}\sqrt{ } \\
\sqrt{ }\end{array}$ & $\begin{array}{l}\sqrt{ } \\
\sqrt{ }\end{array}$ & $\sqrt{ }$ & $\begin{array}{l}\sqrt{ } \\
\sqrt{ }\end{array}$ \\
\hline 4 & $\begin{array}{l}\text { Insurance/bond } \\
\text { - Unfixed material onsite (any } \\
\text { loss or damages) } \\
\text { - Unfixed material offsite (any } \\
\text { loss or damages) }\end{array}$ & $\sqrt{ }$ & $\sqrt{ }$ & & $\sqrt{ }$ & $\sqrt{ }$ & $\begin{array}{l}\sqrt{ } \\
\sqrt{ }\end{array}$ & $\begin{array}{l}\sqrt{ } \\
\sqrt{ }\end{array}$ \\
\hline 5 & $\begin{array}{l}\text { Submission offsite supervision } \\
\text { report } \\
\text { - On site progress } \\
\text { - Off-site progress }\end{array}$ & & $\sqrt{ }$ & & & $\begin{array}{l}\sqrt{ } \\
\sqrt{ }\end{array}$ & $\sqrt{ }$ & \\
\hline 6 & $\begin{array}{l}\text { Extension of time (relevant } \\
\text { events) } \\
\text { - Occurred onsite } \\
\text { - Occurred offsite }\end{array}$ & $\sqrt{ }$ & $\sqrt{ }$ & $\begin{array}{l}\sqrt{ } \\
\sqrt{ }\end{array}$ & $\begin{array}{l}\sqrt{ } \\
\sqrt{ }\end{array}$ & $\sqrt{ }$ & $\sqrt{ }$ & $\begin{array}{l}\sqrt{ } \\
\sqrt{ }\end{array}$ \\
\hline
\end{tabular}

\section{ii. Evaluation of interim payment}

A typical evaluation for interim payment in the standard form of contract usually will look on two things to determine the amount of payment to the contractor, progress of work done, and material on site. For IBS construction approach, this practice is not suitable. It is because most of the work will be done offsite. For example, a conventional construction may take around 8 months to complete the structure elements (column and beam). During that 8 months, the contractor is eligible to claim for the progress of work done and material on the site. By doing so, it directly helps contractor's cash flow. On the other hand, for IBS construction approach, the fabrication process is done offsite 
and delivered to the site within 6 months. Within that 6 months, the contractor is not entitled to claim anything for the interim payment because there is no progress of work done and material on the site. Worse, the contractors are required to pay up front to the IBS manufacturers using their own money before the contractors can claim the amount from the client as reported by Abd Jalil et al. (2016). According to Mohamad Kamar, Alshawi and Abd Hamid (2009), payments from the contractors are expected to be made to the manufacturers before starting fabrication of the IBS components, not when the components are delivered to the site. Findings by Abd Jalil et al. (2016) add up that the current standard form of contract was not suitable for IBS projects because payments to IBS manufacturers will only be made upon delivery of the components to the site, not when the precast components were being manufactured. Based on the report by Abd Jalil et al. (2016) and Blismas and Wakefield (2009), IBS construction approach demands high initial investment capital for fabrication processes. This will lead to a very tight cash flow and may propel other problems. Due to this problem, IBS construction approach is viewed as a threat to their business instead of potential opportunity. This was agreed by Abd Shukor et al. (2011), who stated that more than half of IBS manufacturers were very concerned about payment issues and worry about the commitment and capability of the contractors and clients based on current payment mechanism.

From the study, it shows that majority of the international standard forms of contract allow for material offsite as part of the interim payment. This provision will help the contractor in cash flow management. In PS 2014, the contract allows to claim material offsite with certain conditions, such as invoices and receipts of the material offsite to be submitted to the client, the material offsite are intended for inclusion in the permanents work of the contract, and the material offsite need to be at the premises where they are manufactured or assembled with appropriate storing space complete with visible marked indicated that it is for the permanents works of the contracts. For AS 4300, the contractor needs to list all unfixed material offsite in the "Annexure Part A" section. The client shall be obliged to pay the material offsite listed in the "Annexure Part A" section in the condition that the contractor has paid for the item, properly stored, labelled, and adequately protected. In JCT 2011, all materials offsite are itemised in the "listed item" section. The interim payment shall include the value in the "listed item" section following strict conditions have been fulfilled such as the "listed item" are insured against loss or damage for their full value, "listed item" are at the premises where it have been manufactured or assembled, complete with visible marks by predetermined code for references purposes and their delivery destination.

\section{iii. Inspection, testing of material, goods and equipment}

The local standard form of contract (PWD 203A) is in line with the international form of contract in this aspect. Most of the international standard form of contract allow that the inspection, testing of material, goods, and equipment of the works can be done even though that the works are not yet incorporated onsite. In PWD 203A and JCT 2011, the client may inspect and test any works material, goods, and equipment whether already incorporated in the works or not. In FIDIC 2010, the client has full access to examine, inspect, measure 
or test any material, goods, and equipment during the fabrication at the site or elsewhere. This is suitable for the IBS construction approach as most of the fabrication are being done offsite and all the components are stored in the fabrication yard may not be incorporated in works onsite yet. This provision is giving the client the authority to access the offsite premises to inspect or test any material, goods, and equipment that relates to the project during the fabrication process.

\section{iv. Insurance/bond}

Most of the international form of the contract required the contractor to take insurance/bond for the unfixed material offsite. This will act as a guaranteed mechanism for the client if the contractor fails to deliver. The client will also be more secure and comfortable to pay for the material offsite since everything is being insured/bonded. In AS 4300, the contractor needs to take insurance that covers things in storage on and offsite including the transit journey to the site. For JCT 2011, the contractor needs to insure all the unfixed material offsite against loss or damages in full value starting from fabrication process, storing period, and until delivering it to the site.

\section{v. Submission offsite supervision report}

As a client, it is a good practice to monitor the progress not only onsite but also offsite activities. For IBS construction approach, most of the fabrication works are done offsite, therefore, monitoring offsite is consider crucial to ensure the contractor manage to fabricate and deliver the IBS components based on the stipulated time, cost, and quality. Most of the standard form of contract only required producing onsite supervision report. Only one standard form of contract (FIDIC 2010) required the contractor to submit supervision on and offsite reports. For the offsite progress, the contractor needs to furnish certain information such as the name of the manufacturer, location of manufacturer, commencement of manufacturing, percentage progress, expected date of shipment, and arrival at the site. This provision can be adopted for the local standard form of contract as offsite supervision report that can be monitored closely by the client.

\section{vi. Extension of time}

In certain cases, the contractor extension of time is needed due to occurrence of relevant events. Most of the standard form of contract only acknowledged if the relevant events happened onsite. As for IBS construction approach, it is appropriate to consider relevant events occur offsite too as most of the construction activities are done offsite. In PAM 2006, PS 2014, and JCT 2011, there is a provision for extension of time stated that if there are civil commotions, strike or lockout affecting any of the trades employed upon the work or any trades engaged in the preparation, manufacture or transportation of any material and goods required for the works. This provision is highlighting that the offsite activities need to be considered as the whole construction progress. It is suitable for IBS construction approach, where the contractor feels secure and comfortable to adopt the IBS construction approach. 


\section{CONCLUSION}

From the study conducted, it clearly shows that Malaysia's standard forms of contract are still lacking in the provision for IBS or prefabricated construction activities. It creates uncertainty and potential risk to the industry players thus low adoption in IBS construction approach. For IBS construction approach to be effective, attention needs to be placed not only on the technical part but also in the procurement aspect. It requires a fairer and practical standard form of contract to tailor to IBS construction approach. It needs to consider not only on onsite but also offsite activities and progress. To ensure that IBS construction approach can be adopted effectively and efficiently, few provision that suits the interest of IBS construction approach are required. Previous researches and findings from the document analysis show that the current standard form of contract does not provide enough provision for the IBS construction approach. Therefore, it is necessary to enhance the standard form of contract to suit IBS construction approach hence accelerate the adoption of IBS construction. The output of this research will hopefully illustrate good insights to the industry and help to accelerate the adoption of IBS construction in Malaysia as a whole.

\section{ACKNOWLEDGEMENTS}

The paper is a part of the author's ongoing doctoral research work at Universiti Teknologi Mara (UiTM). Acknowledgements are also due to IBS Centre, CIDB, UiTM, and Infrastructure University Kuala Lumpur (IUKL) that are directly or indirectly involved in the whole research process.

\section{REFERENCES}

Abd Hamid, Z., Mohamad Kamar, K.A., Alshawi, M., Mohd Zain, M.Z., Ghani, M.K. and Abdul Rahim, A.H. (2011). Industrialised Building System (IBS) construction supply-chain strategies of Malaysian contractors. 6th International Conference on Construction in the 21 st Century, "Construction Challenges in the New Decade". 5-7 July 2011. Available at: http://www.vertilite.asia/f/2012/11//BSSupply-Chain-Strategy-for-Contractor.pdf [Accessed on 15 November 2016].

Abd Jalil, A., Nuruddin, A.R., Jaafar, M. and Mydin, M.A.O. (2016). A new procurement method for housing projects implementing IBS modular system CIDB. IBS DIGEST, 2: 12-17. Available at: https://www.facebook.com/JomIBS/ [Accessed on 4 January 2017].

Abd Shukor, A.S., Mohammad, M.F. and Mahbub, R. (2011). Supply chain integration challenges in project procurement in Malaysia: IBS contractors' perspective. Management and Innovation for a Sustainable Built Environment MISBE 2011. Amsterdam, 20-23 June 2011.

Abd Shukor, A.S. Mohammad, M.F., Mahbub, R. and Ismail, F. (2011). Supply chain management in IBS in Malaysia construction industry. The Build Environment Review, 4(Spl. 1): 108. 
Ahmad Smore, M. (2007). Overview of the 1999 FIDIC Contract forms and the multilateral developments banks contract. Available at: https://pecongress. org.pk/images/upload/books/P255.pdf [Accessed on 6 September 2016].

Ashworth, A. (2006). Contractual procedures in the construction industry. UK: Pearson/Prentice Hall.

Blismas, N. and Wakefield, R. (2009). Drivers, constraints and the future of offsite manufacture in Australia. Construction Innovation, 9(1): 72-83. https://doi. org/10.1108/14714170910931552

Broome, J. and Hayes, R. (1997). A comparison of the clarity of traditional construction contracts and of the new engineering contract. International Journal of Project Management, 15(4): 255-261. https://doi.org/10.1016/ S0263-7863(96)00078-6

Building and Construction Authority. (2015). Public sector standard conditions of contract (PSSCOC). Available at: https://www.bca.gov.sg/PSSCOC/psscoc_ construction_works.html [Accessed on 18 October 2016].

Chung, L. and Kadir, A. (2007). Implementation Strategy for Industrialized Building System. Johor Bahru, Malaysia: Universiti Teknologi Malaysia.

Construction Industry Development Board (CIDB). (2015a). Construction industry master plan 2 (CIMP 2 2016-2020). Kuala Lumpur: CIBD, Ministry of Works Malaysia.

CIDB. (2015b). Input-output table. Kuala Lumpur: CIBD, Ministry of Works Malaysia.

CIDB. (2014). IBS-roadmap 2011-2015. Kuala Lumpur: CIBD, Ministry of Works Malaysia. Available at: http://www.cidb.gov.my/cidbv4/?option=com_ content\&view $=$ article\&id=594:ibs-roadmap-201 $1-2015 \&$ catid $=57 \& 1$ temid $=5 \overline{7}$ 7\&lang=en. [Accessed on 6 November 2015].

CIDB. (2010). IBS Road Map. Kuala Lumpur: CIBD, Ministry of Works Malaysia.

CIDB. (2006). Construction industry master plan 2006-2015 (CIMP 2006-2015). Kuala Lumpur: CIBD, Ministry of Works Malaysia.

Construction Research Institute of Malaysia (CREAM). (2011). The current state of industrialised building system (IBS) construction in Malaysia. Proceedings of lst IBS Roundtable Workshop. Kuala Lumpur: Makmal Kerja Raya Malaysia. Available at: http://medcontent.metapress.com/index/A65RM03P4874243N. pdf [Accessed on 17 June 2015].

Gandu, Y.J., Ali, and Chindo, P.G. (2009). Bidding model for sustainable projects using the traditional procurement method. The Information Manager, 9(2): 36-43. http://doi.org/10.4314/tim.v9i2.63663

Gibb, A.G.F. (2001). Pre-assembly in construction: A review of recent and current industry and research initiatives on pre-assembly in construction. Construction Research \& Innovation Strategy Panel CRISP Consultancy Commission 00/19. London: CRISP Consultancy Commission.

Harmon, K.M.J. (2003). Resolution of construction disputes: A review of current methodologies. Journal of Leadership and Management in Engineering, 3(4): 187-201. https://doi.org/10.1061/(ASCE) 1532-6748(2003)3:4(187)

Heap, Y.C., Balamuralithara, B. and Chong, S.C. (2011). Construction contract administration in Malaysia using DFD: A conceptual model. Industrial Management and Data Systems, 111(9): 1449-1464. https://doi. org/10.1108/026355711111182782

Hellard, B.R. (1997). Preventing and solving construction disputes. New York: Litton Educational Publishing Company. 
IBS Centre. (2007). IBS roadmap review (final report). Kuala Lumpur: CIBD, Ministry of Works Malaysia

Jaafar, M. and Radzi, N.M. (2012). Building procurement in a developing country: A comparison study between public and private sectors. International Journal of Procurement Management, 5(5): 608-626.

Jaafar, M. and Radzi, N.M. (2013). Level of satisfaction and issues with procurement systems used in the Malaysian public sector. Australasian Journal of Construction Economics and Building, 13(1): 50-65. https://doi.org/10.5130/ ajceb.v13i1.2830

Kamaruddin, S., Mohammad, M., Mahbub, R. and Yunus, R. (2013). Perception towards cost implication of mechanisation and automation approach in IBS projects in Malaysia. 29th Annual ARCOM Conference. Reading, UK, 2-4 September 2013.

Kamaruddin, S.S., Mohammad, M.F. and Mahbub, R. (2013). Enhancing the quality of life by adopting IBS: An economic perspective on mechanisation and automation. Procedia - Social and Behavioral Sciences, 101: 71-80. https:// doi.org/10.1016/j.sbspro.2013.07.180

Mahdi, S.A. (2001). Gateway to arbitration: Issues of contract formation under the U.C.C. and the enforceability of arbitration clauses included in standard form contracts shipped with goods. Northwestern University Law Review, 96(1): 403.

Malaysian Construction and Contract Law. (2012). PAM 2006 Standard form of building contract. Available at: https://simplymalaysia.wordpress.com/ standard-forms-of-contract/domestic-standard-contract-forms/pam-2006/ [Accessed on 8 December 2015].

Mohamad Kamar, K.A., Alshawi, M., Abd. Hamid, Z., Mohd Nawi, M.N. and Ahmad Tarmidzi Haron, M.R.A. (2009). Industrialised building system (IBS): A review of experiences in UK and Malaysian construction industry. 2nd Construction Industry Research Achievement International Conference (CIRAIC). Kuala Lumpur: Construction Research Institute of Malaysia, 1-12.

Mohamad Kamar, K.A., Alshawi, M. and Abd Hamid, Z. (2009). Barriers to industrialized building system (IBS): The case of Malaysia. 9th International Postgraduate Research Conference (IPGRC). The University of Salford, UK, 29-30th January 2009.

Mohammad, M.F. (2013). Construction environment: Adopting IBS construction approach towards achieving sustainable development. Procedia-Social and Behavioral Sciences, 85: 8-15. https://doi.org/10.1016/j.sbspro.2013.08.332

Mohd Fateh, M.A., Mohammad, F.M. and Abd Shukor, A.S. (2016). Review in formulating the standard form of contract for Industrialized Building System (IBS) construction approach in Malaysia. The 9th International Unimas Stem Engineering Conference (ENCON 2016) 'Innovative Solutions for Engineering and Technology Challenges'. https://doi.org/10.1051/ matecconf/20178701001

Muhamad Halil, F., Mohammad, M.F., Mahbub, R. and Abd Rahim, S.F. (2015). Sustainable value through the implementation of strategic partnering in industrialised building system (IBS). International Symposium in Developing Economies: Commonalities among diversities. Available at: http://www. irbnet.de/daten/iconda/CIB18128.pdf [Accessed on 1 January 2016]. 
Musa, M.F., Mohammad, M.F., Yusof, M.R. and Mahbub, R. (2015). The way forward for industrialised building system (IBS) in Malaysia. Proceedings of the International Civil and Infrastructure Engineering Conference 2014. 28th September to 1st October 2015. Singapore: Springer Singapore, 163-175. https://doi.org/10.1007/978-981-287-290-6

Nawi, M.N.M., Lee, A., Mohamad Kamar, K.A. and Abd Hamid, Z. (2011). A critical literature review on the concept of team integration in industrialised building System (IBS) project. Malaysian Construction Research Journal, 9(2):1-17.

Preuss, L. (2009). Addressing sustainable development through public procurement: The case of local government. Supply Chain Management, 14(3): 213-223. https://doi.org/10.1108/13598540910954557

Rajoo, S., Davidson, W.S.W. and Singh, H. (2010). The PAM 2006 Standard Form of Building Contract. Available at: http://www.lexisnexis.com.my/store/catalog/ apac/productdetail.jsp? \&prodld=prod620010\# [Accessed on 9 December 2015].

Ramus, J. and Birchall, S. (1996). Contract practice for surveyors, 3rd Ed. Buckinghamshire, UK: Laxton's Publishing Limited.

Sarja, A. (1998). Open and industrialised building. Abingdon, UK: Routledge.

Sharkey, J., Bell, M., Jocic, W. and Marginean, R. (2014). Standard forms of contract in the Australian construction industry. Melbourne: The University of Melbourne.

Singh, H. (2011a). Harbans' engineering and construction contracts management (law and principles). Singapore: LexisNexis.

Singh, H. (201 lb). Harbans' engineering and construction contracts management (pre-contract award practice). Singapore: LexisNexis.

The Joint Contracts Tribunal Limited. (2016). Our history. Available at: http:// corporate.jctltd.co.uk/about-us/our-history/ [Accessed on 18 October 2016].

The UK Government Department of Trade and Industry (DTI). (2004). Modern methods of construction in Germany - playing the off-site rule. Global Watch Mission Report. United Kingdom: DTI.

Ting, S.N. and Chin, L.W. (2013). Selection criteria and the related sub-criteria for the selection of standard form of contract for construction projects in Sarawak. UNIMAS E-Journal of Civil Engineering, 4(2): 33-38.

Wilkinson, S. and Scofield, R. (2010). Management for the New Zealand construction industry, 2nd Ed. Melbourne: Pearson Education Australia.

Zakaria, Z., Ismail, S. and Md Yusof, A. (2013). An overview of comparison between construction contracts in Malaysia: The roles and responsibilities of contract administrator in achieving final account closing success. Proceedings of the 2013 International Conference on Education and Educational Technologies (EET 2013). Rhodes Island, Greece, July 16-19 2013. Montclair, USA: Incase, $34-41$.

Zolkafli@Zulkifli, U.K., Zakaria, N., Salleh, H., Ali, A.S. and Yeah, C.L. (2011). The comparative study of international standard form of building contract: FIDIC conditions of contracts for construction (the new red book 1999) and Malaysian's standard form of building contract (PWD 203A). International Engineering Education Conference 2011 . Madinah al- Munawarah, Kingdom of Saudi Arabia, 25-27 December 2011. 